\title{
Leprosy Among School Children in Greater Bombay: Clinical Features
}

\author{
R. GANAPATI, $*$ S. S. NAIK $†$ AND S. S. PANDYA + \\ Acworth Leprosy Hospital, Wadala, Bombay 400 031, India
}

\begin{abstract}
Clinical observations on 1265 cases identified as suffering from leprosy in the course of 4 studies based on surveys covering a total population of nearly 180,000 school children are presented.

$94.1 \%$ of the cases were of the non-lepromatous type. While $75.3 \%$ had early single lesions, $24.7 \%$ had either the potential to develop into progressive forms in view of the multiplicity of lesions or were already in an advanced stage of the disease. Polyneuritic leprosy together with intermediate and lepromatous types representing $5.8 \%$ of all cases (24 cases were confirmed to be smear positive) belonged to the groups posing therapeutic as well as public health problems. In general the morbidity due to the disease was more marked in children attending municipal schools as compared to private schools.

Analysis of 953 cases with single lesions revealed greater frequency of distribution $(58.4 \%)$ of patches in parts of the body which are generally covered. It is striking that $26.4 \%$ of the solitary lesions was found in the gluteal region and thighs, emphasizing the need for thorough examination of these parts during surveys.
\end{abstract}

\section{Introduction}

This presentation summarises the clinical observations on the large series of leprosy cases detected through school surveys in Greater Bombay during the years 1970 to 1975 . The 180,000 children from whom these data are derived represent a significant section of the child population of the city. The surveys reflect not only the extent to which children are exposed to the disease but also the morbidity due to childhood leprosy.

\section{Material}

Results of clinical examination of 1265 children identified as suffering from leprosy in the course of 4 studies based on surveys of municipal and private schools were available for analysis. All the cases have been pooled for final assessment. The details of various groups of child population surveyed and the prevalence figures are shown in Table 1.

* Present address: Medical Director, Greater Madras Leprosy Treatment and Health Education Scheme, 29/C Gajapathy Naidu Street, Shenoynagar, Madras 6000 30, S. India.

$\dagger$ Research Assistant

$\ddagger$ Research Officer, R.R.E. Society.

Received for publication 21 st August, 1975. 
TABLE 1

Prevalence rates in the various samples of population

\begin{tabular}{|c|c|c|c|c|c|}
\hline $\begin{array}{l}\text { Sample } \\
\text { No. }\end{array}$ & Sample & $\begin{array}{l}\text { Child } \\
\text { population } \\
\text { examined }\end{array}$ & $\begin{array}{l}\text { No. of } \\
\text { leprosy cases } \\
\text { detected }\end{array}$ & $\begin{array}{l}\text { Prevalence } \\
\text { rate } \\
\text { per } 1000\end{array}$ & Reference \\
\hline \multirow[t]{3}{*}{ I } & $\begin{array}{l}\text { 1. Random sample survey } \\
\text { of all municipal } \\
\text { schools in Bombay }\end{array}$ & 50,697 & $152^{a}$ & 3.0 & \\
\hline & $\begin{array}{l}\text { 2. Municipal schools in } \\
\text { Dharavi, a known } \\
\text { endemic area in } \\
\text { Central Bombay }\end{array}$ & 2,932 & 33 & 11.3 & $\begin{array}{l}\text { Ganapati } \\
\text { et al. } \\
\text { (1973) }\end{array}$ \\
\hline & $\begin{array}{l}\text { 3. Municipal and private } \\
\text { schools in Abyudaya } \\
\text { Nagar, an industrial } \\
\text { colony in Central } \\
\text { Bombay }\end{array}$ & 10,460 & 25 & 2.4 & \\
\hline II & $\begin{array}{l}\text { Muncipal schools situated } \\
\text { in } 10 \text { presumably } \\
\text { endemic pockets }\end{array}$ & 67,857 & 733 & 10.8 & $\begin{array}{l}\text { Ganapati } \\
\text { et al. } \\
(1974)\end{array}$ \\
\hline III & $\begin{array}{l}\text { Private schools in } \\
\text { Andheri, a northern } \\
\text { suburb of Bombay }\end{array}$ & 21,508 & 141 & 6.5 & $\begin{array}{l}\text { Pandya } \\
\text { et al. } \\
(1974)\end{array}$ \\
\hline \multirow[t]{2}{*}{ IV } & $\begin{array}{l}\text { Private schools in } \\
\text { Chembur, a northern } \\
\text { suburb of Bombay }\end{array}$ & 29,293 & 181 & 6.2 & $\begin{array}{c}\text { Unpublished } \\
\text { data }\end{array}$ \\
\hline & Total & 182,747 & 1265 & 6.9 & \\
\hline
\end{tabular}

${ }^{a}$ To the 151 cases reported in the reference cited one case has been added which was a doubtful case under observation, later confirmed as tuberculoid leprosy.

The clinical examination of the children in all these surveys was essentially done by the medical staff from the Acworth Leprosy Hospital, well trained in the out-patient clinic of the hospital. The children were examined in a properly lighted room or in an open space within the premises of the schools, after stripping them to the maximum extent possible. A majority of the cases diagnosed in the field as well as suspected cases attended the hospital clinic for confirmation by senior doctors and for skin smear examination. Remaining cases were registered in the field.

\section{Observations and Comments}

The age distribution of 1265 cases ( 811 males and 454 females) is given in Table 2.

Clinical data in respect of municipal schools (catering almost exclusively to the poorer sections of the community) and private schools are given in Table 3 , in which Parts I and II (vide Table 1) represent the findings from the municipal group and Parts III and IV (vide Table 1) those from the private school group.

The non-lepromatous cases have been divided into those with skin manifestations alone and those showing involvement of nerve trunks, since the latter group 
TABLE 2

\begin{tabular}{ccc}
\hline Age (years) & No. of cases & $\%$ \\
\hline $5-7$ & 232 & 18.3 \\
$8-10$ & 476 & 37.6 \\
$11-13$ & 363 & 28.7 \\
$14-16$ & 175 & 13.9 \\
$17-21$ & 19 & 1.5 \\
$5-21$ years & 1265 & 100 \\
\hline
\end{tabular}

carries a less favourable prognosis. It is seen that $94.3 \%$ of the cases were of the non-lepromatous type, the vast majority of them $(75.3 \%$ of the total) having solitary early lesions of the indeterminate, tuberculoid or maculo-anaesthetic types. Even granting that many such early single lesions may possibly show a tendency to regress spontaneously (Noordeen, 1975, Browne 1975), a significant proportion of cases $(24.7 \%$ ) had either the potential to develop into progressive forms in view of the multiplicity of lesions or were already in an advanced stage of the disease.

Polyneuritic leprosy in an early or advanced stage was encountered in $3 \%$. The higher prevalence of this type in the municipal groups is of concern since these children need careful management to prevent or arrest progressive deformities. It should be noted that polyneuritic leprosy was 3 times more frequent in these children than in those attending private schools. It is also noteworthy that 11 children had primary polyneuritis without any obvious skin lesions and 3 such cases were in the early stages, detectable only by palpation of nerve trunks and careful examination for sensory changes. If, as is all too common, examination for skin patches alone is given importance in leprosy surveys, such cases will be missed. We have grouped intermediate and lepromatous types together as these were suspected on clinical examination to be bacteriologically positive and hence important from the public health point of view. Out of 34 such cases $(2.8 \%)$ referred for bacteriological examination, only 24 attended the clinic and their

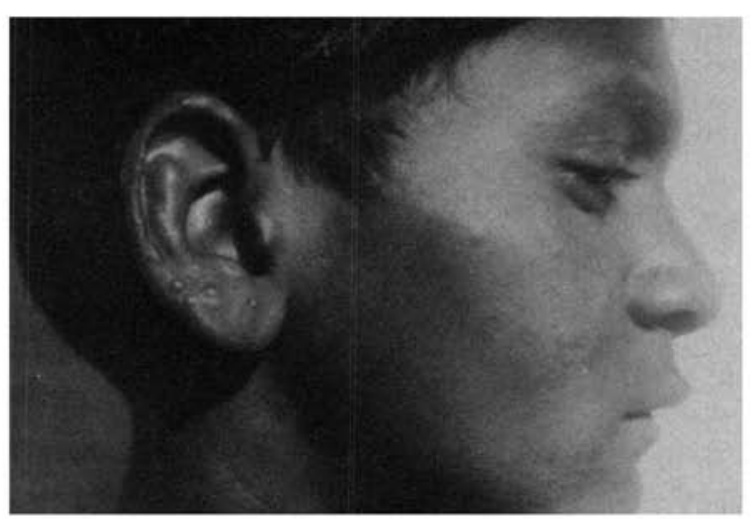

Fig. 1. Moderately advanced lepromatous leprosy in a school child. 
skin smears were confirmed to be positive for AFB in all cases. Eight cases showed frank lepromatous features, 5 out of which had moderately advanced (L2) stages of the disease (Fig. 1). It is interesting that in one class in a municipal school, we encountered a pair of twins aged 5 years, suffering from borderline leprosy (smear-positive).

Although borderline and lepromatous types were about $1 \frac{1}{2}$ times more frequent in municipal schools than in private schools, it is important to emphasize the presence of previously unrecognized (or misdiagnosed) cases belonging to these types of leprosy even in children whose parents have access to consultant medical opinion. In fact 2 such patients were encountered among the children of well-to-do parents, attending private schools.

Polyneuritic leprosy together with intermediate and lepromatous types, representing $5.8 \%$ of all the cases detected, constitute a comparatively difficult group to treat and the infectious cases among them also pose a hazard to contacts.

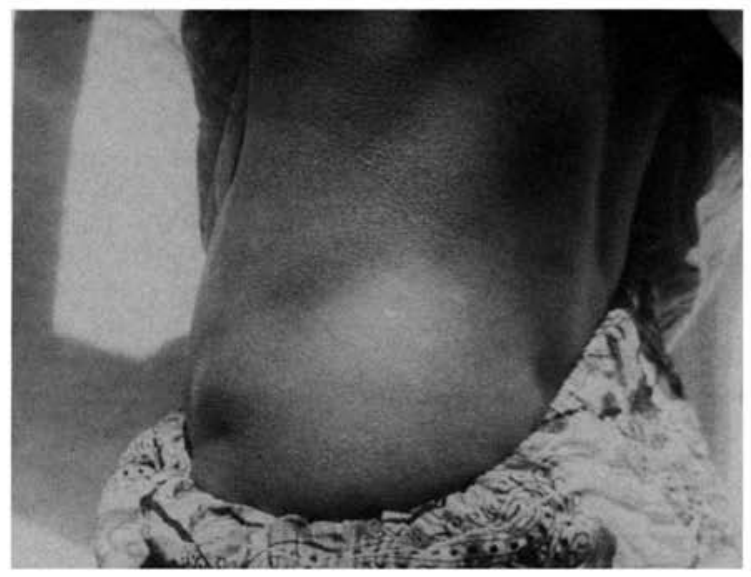

Fig. 2. Leprosy lesion on the loin.

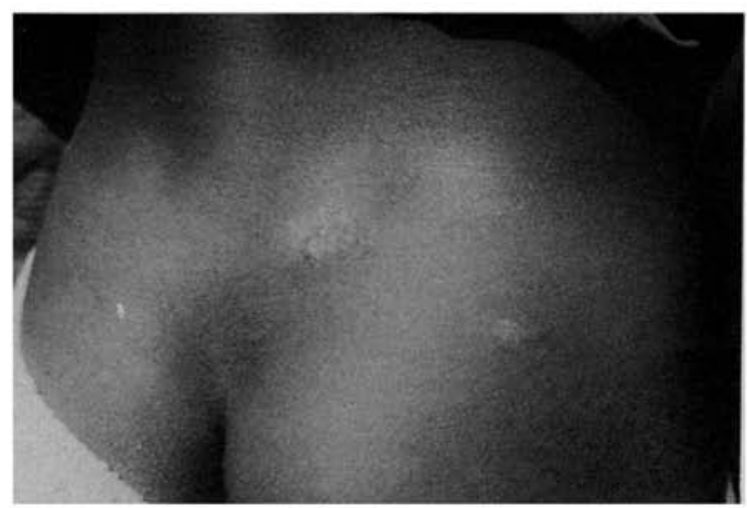

Fig. 3. Leprosy lesions on the waist. 
TABLE 3

Clinical details

\begin{tabular}{|c|c|c|c|c|c|c|c|c|c|c|c|c|c|}
\hline \multirow{4}{*}{$\begin{array}{l}\text { Sample } \\
\text { (vide } \\
\text { Table 1) }\end{array}$} & \multicolumn{9}{|c|}{ Non-lepromatous group } & \multirow{2}{*}{\multicolumn{4}{|c|}{$\begin{array}{c}\text { Lepromatous and intermediate } \\
\text { (or borderline) } \\
\text { groups }\end{array}$}} \\
\hline & \multirow[t]{3}{*}{$\begin{array}{l}\text { No. of } \\
\text { Cases }\end{array}$} & \multicolumn{4}{|c|}{$\begin{array}{l}\text { Without Polyneuritic } \\
\text { Involvement }\end{array}$} & \multicolumn{4}{|c|}{$\begin{array}{l}\text { With Polyneuritic } \\
\text { Involvement }\end{array}$} & & & & \\
\hline & & \multirow{2}{*}{ Early } & \multirow{2}{*}{ Advanced } & \multicolumn{2}{|c|}{ Total } & \multirow{2}{*}{ Early } & \multirow{2}{*}{ Advanced } & \multicolumn{2}{|c|}{ Total } & \multirow{2}{*}{ Early } & \multirow{2}{*}{ Advanced } & \multicolumn{2}{|c|}{ Total } \\
\hline & & & & No. & $\%$ & & & No. & $\%$ & & & No. & $\%$ \\
\hline $\begin{array}{l}\text { I and II } \\
\text { (municipal } \\
\text { schools) }\end{array}$ & 943 & 688 & 193 & 881 & 93.4 & $20^{a}$ & $14^{b}$ & 34 & 3.6 & 3 & 25 & $28^{d}$ & 2.9 \\
\hline $\begin{array}{l}\text { III and IV } \\
\text { (private } \\
\text { schools) }\end{array}$ & 322 & 265 & 47 & 312 & 96.9 & 2 & 2 & 4 & 1.2 & - & 6 & 6 & 1.9 \\
\hline Total & 1265 & 953 & 240 & 1193 & 94.1 & 22 & 16 & 38 & 3.0 & 3 & $31^{c}$ & $34^{c}$ & 2.8 \\
\hline
\end{tabular}

${ }^{a} 3$ cases in this group had primary polyneuritis without skin lesions.

$b 8$ cases in this group had primary polyneuritis without skin lesions.

$c 24$ cases in this group were confirmed to be positive by smear examination. The remaining 10 cases were not available for smear examination.

$d 8$ cases showed frank lepromatous features out of which 5 were in a moderately advanced stage (L2). 
TABLE 4

Distribution of single lesions in 953 cases of childhood leprosy

\begin{tabular}{|c|c|c|}
\hline Site of lesion & No. & $\%$ \\
\hline \multicolumn{3}{|l|}{ Face and neck } \\
\hline Cheeks & 79 & 8.3 \\
\hline Forehead & 7 & 0.7 \\
\hline Orbital region & 3 & 0.3 \\
\hline Mandibular and mental regions & 24 & 2.5 \\
\hline Ears & 6 & 0.6 \\
\hline Neck & 2 & 0.2 \\
\hline Total & 121 & 12.6 \\
\hline \multicolumn{3}{|l|}{ Trunk } \\
\hline \multicolumn{3}{|l|}{ Upper part of the back } \\
\hline (Scapular, infrascapular regions) & 73 & 7.7 \\
\hline Lumbar regions & 37 & 3.9 \\
\hline Chest & 17 & 1.8 \\
\hline Abdomen & 26 & 2.7 \\
\hline Total & 153 & 16.1 \\
\hline \multicolumn{3}{|l|}{ Lower limbs } \\
\hline Thighs & 168 & 17.6 \\
\hline Buttocks & 84 & 8.8 \\
\hline Knees & 51 & 5.4 \\
\hline Legs & 41 & 4.3 \\
\hline Feet & 2 & 0.2 \\
\hline Total & 346 & 36.3 \\
\hline \multicolumn{3}{|l|}{ Upper limbs } \\
\hline Arms & 120 & 12.6 \\
\hline Deltoid region & 31 & 3.2 \\
\hline Elbows & 91 & 9.6 \\
\hline Forearms & 67 & 7.1 \\
\hline Wrist & 18 & 1.9 \\
\hline Hands & 6 & 0.6 \\
\hline Total & 333 & 35.0 \\
\hline
\end{tabular}

TABLE 5

Distribution of single lesions on covered and uncovered parts

\begin{tabular}{lrr}
\hline Site of lesion & No. & $\%$ \\
\hline Covered parts & & \\
$\quad$ Chest and back & & \\
Abdomen and lumbar regions & 153 & 16.1 \\
Shoulders and arms & 151 & 15.8 \\
Thighs & 168 & 17.6 \\
Gluteal region & 84 & 8.8 \\
Total & 556 & 58.3 \\
Uncovered parts & & \\
Face and neck & 121 & 12.6 \\
Elbows & 91 & 9.6 \\
Forearms and hands & 91 & 9.6 \\
Knees & 51 & 5.4 \\
Legs & 43 & 4.5 \\
Total & 397 & 41.7 \\
\hline
\end{tabular}




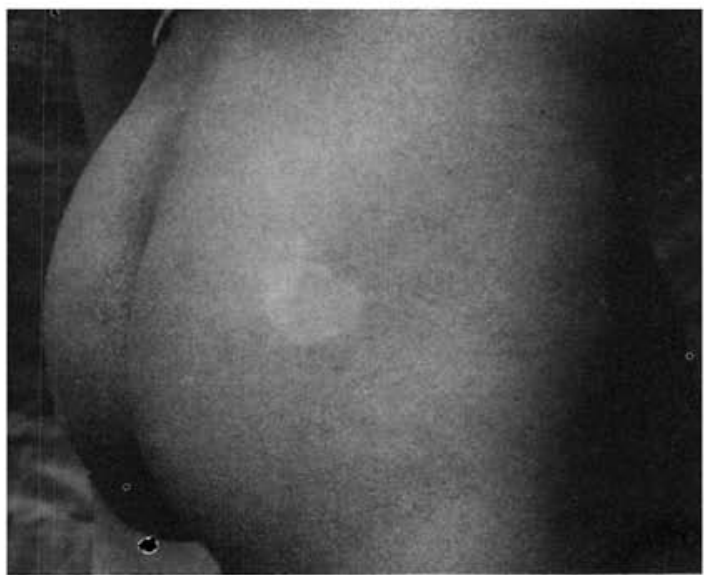

Fig. 4. Leprosy lesion on the buttock.

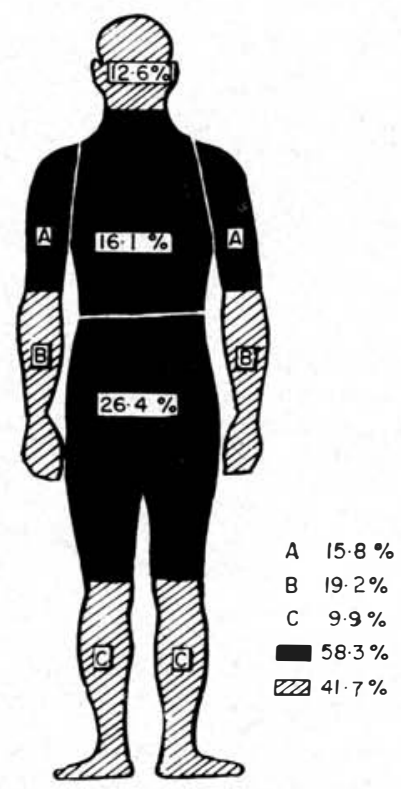

Fig. 5. Distribution of single lesions.

An earlier analysis (Ganapati et al., 1971) of 1000 children attending clinics showed that this group formed $31.3 \%$. The difference is attributable to the fact that the survey sample comprises a large number of children whose disease was diagnosed at a very early stage. This proves the advantage of detecting the vulnerable groups through surveys before they pass on to a stage likely to pose therapeutic as well as public health problems. 


\section{SINGLE LESIONS}

The data obtained from these surveys are admirably suited for analysis from the point of view of occurrence of first lesions in the body in view of the large number of children (953 cases) exhibiting single lesions. Analysis of this nature has been done by a few authors in the past to find out whether the cutaneous distribution of lesions supports the theory that the portal of entry of $M$. leprae is the skin.

Table 4 shows the distribution of single lesions in various parts of the body:

In Table 5 and Fig. 5 we have attempted to split up the data into two groups, (viz) the lesions noticed in the generally covered parts, i.e., trunk, shoulders, arms, gluteal regions and thighs, and those seen in mostly uncovered areas of the body, i.e. face, elbows, forearms, hands, knees and legs.

The early lesions are seen to a greater extent in the generally covered parts. If such lesions were to have developed at the point of entry of $M$. leprae, one would have expected greater frequency of occurrence in the exposed parts of the body. Our findings are in line with those of Bechelli et al. (1973), who made their observation on single lesions in 469 children in Burma. Bedi et al. (1975) however, were able to establish a correlation between the clothing pattern and the distribution of single tuberculoid lesions in adults.

Apart from the credibility of the inference from such studies on the portal of entry of the organism, one cannot but be struck by the significant proportion of cases (252 out of 953 or $26.4 \%$ ) with solitary lesions on the gluteal regions and the thighs. The importance of careful examination of these parts of the body cannot be over-emphasized. Lesions have come to light in several instances by stripping the child to expose the waist and upper parts of the buttocks properly (Figs 2, 3 and 4).

\section{Acknowledgement}

The surveys were conducted by the following institutions and we thank the respective authorities for permission granted to make use of the data for clinical analysis: Acworth Leprosy Hospital, Wadala, Bombay 31; Acworth Leprosy Hospital, Society for Research, Rehabilitation and Education in Leprosy, Wadala, Bombay 31; Maharashtra Lokahita Samithi, Santa Cruz, Bombay 54.

Part IV (vide, Table 1) of the survey was possible through the kind donation from the Rotary Club Chembur, Bombay.

\section{References}

Bechelli, L. M., Garbajosa, P. G., Gyi, M. G., Dominguez, V. M. and Quagliato, R. (1975). Site of early skin lesions in children with leprosy. Bull. Wld Hlth Org. 48, 107.

Bedi, B. M. S., Narayanan, E., Doss, A. C., Kirchheimer, W. F., and Balasubrahmanyan, M. (1975). Distribution of single lesion of tuberculoid leprosy. Lepr. India 47, 15.

Browne, S. G. (1974). Self-healing leprosy: report on 2749 patients. Lepr. Rev. 45, 104.

Ganapati, R., Naik, S. S., Acharekar, M. Y. and Pade, S. S. (1974). Leprosy Endemicity in Bombay-An Assessment through Surveys of Municipal Schools. Paper presented at the Seminar of the Indian Association of Leprologists, Bombay, November 1974.

Ganapati, R., Naik, S. S., Sane, A. B. and Parikh, A. C. (1973). Leprosy among school children in Greater Bombay. Results of Surveys, Lepr. India 45, 151.

Ganapati, R., Parikh, A.C. and Sane, A. B. (1971). Prevalence of leprosy among school children in Greater Bombay, Pediat. Clin. India 6, 13.

Noordeen, S. K. (1975). Evolution of tuberculoid leprosy in a community. Lepr. India 47, 85.

Pandya, S. S., Torriani, C. and Fernandez, I. (1974). Leprosy endemicity in Bombay-an assessment through surveys of private schools. Paper presented at the Seminar of the Indian Association of Leprologists, Bombay, November 1974. 